\title{
ВПЛИВ ТРИВАЛОСТІ ЛАКТАЦІЇ, ПОРИ РОКУ, ВІКУ, ПОРОДНИХ ПОЄДНАНЬ СВИНОМАТОК НА ВІДТВОРЮВАЛЬНІ ПОКАЗНИКИ ЇХ ПРОДУКТИВНОСТІ
}

\author{
Швачка Руслан Петрович \\ аспірант \\ Сумський національний аграрний університет \\ ORCID: 0000-0001-7185-4343 \\ E-mail: ruslans19hvachka@gmail.com
}

В статті, шляхом проведення чотирифракторного дисперсійного аналізу, досліджувалась сила впливу тривалості лактації, віку свиноматок, їх породних поєднань в різні пори року, та взаємодії цих факторів на зміну окремих показників відтворювальної продуктивності свиноматок. Встановлено, що тривалість підсисного періоду найбільщ суттєєво впливає на масу гнізда поросят при відлучені - 73,0\%, - середню масу одного поросяти при відлучені - 64,4\%, - абсолютні прирости поросят в підсисний період - 63,0\%, середньодобові прирости в цей період - 8,4\%, відносні прирости в підсисний період - 1,2\%, збереженість поросят до відлучення - 0,7\% і масу гнізда при народжені - 1,9\% та кількість поросят при відлучені - 0,4\% та не мав впливу на загальну кількість поросят при народжені і багатоплідність свиноматок. Пора року мала вплив на збереженість поросят до відлучення - 2,1\%, їх кількість при відлучені та середньодобові прирости в підсисний період по 1,6\%, відносні прирости в ией період - 1,2\%, абсолютний приріст поросят в підсисний період - 0,6\%, масу одного поросяти та масу гнізда при відлучені - відповідно 0,5\% та 0,4\% і зовсім не вплинула на загальну кількість поросят при народжені, багатоплідність та масу гнізда поросят при народжені. Вік свиноматки мав вірогідний вплив на всі досліджувані показники. Найбільший вплив він спричинив на кількість поросят при відлучені - 8,3\%, їх збереженість до відлучення - 6,7\%, середньодобові прирости в підсисний період - 4,5\%, масу гнізда поросят при народжені - 2,3\% і багатоплідність свиноматок $-2,2 \%$, абсолютний приріст поросят в підсисний період 2,0\%, масу одного поросяти та масу гнізда при відлучені -1,9\%, на загальну кількість поросят при народжені - 1,7\%, відносний приріст поросят в підсисний

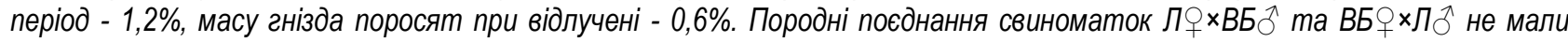
вірогідного впливу на показники відтворювальної здатності, що вивчались.

Ключові слова: свиноматка, поросята, підсисний період, термін відлучення поросят, багатоплідність, збереженість, поєднання породи.

DOI: https://doi.org/10.32845/bsnau.lvst.2021.3.15

Україна є традиційно країною де свинарство споконвіку було основною галуззю тваринництва. За даними В. В Немченко [16], воно забезпечує третину попиту населення України на м'ясну продукцію. Сучасні тенденції в свинарстві провідних країн світу характеризується його інтенсифікацією, концентрацією виробництва, що вимагає постійного підвищення продуктивності тварин для забезпечення конкурентоспроможності виробництва свинини [5, 23]. Аналогічні вимоги ринку України спричиняють використання інтенсивних технологій введення свинарства, які суттєво відрізняються від традиційних. Одною з найважливіших дільниць виробництва в свинарстві, на думку В. Волощука [7], И Моpapy [15], М. Повода [21], А.Черненко [31], T. Whiting [41], $\epsilon$ дільниця відтворення, а основним засобом виробництва на ній - продуктивна свиноматка, від раціонального використання якої залежить ефективність виробництва в цілому на підприємстві. 3 метою підвищення ефективності використання маточного поголів'я застосовуються різноманітні технологічні прийоми, одним з яких є скорочення тривалості підсисного періоду [2, 4, 39].

Останніми роками в світі превалює тенденція до скорочення підсисного періоду у свиноматок, що зумовлено розвитком генетики, біохімії, фізіології та інших наук. Також цьому сприяє застосування останніх досягнень в технології виробництва комбікормів з добавлянням ферментів, пробіотиків, біологічно активних речовин $[4,6]$. На сьогодні в основному відлучають поросят від свиноматок у США у 14 денному віці, у Канаді - 14-16 днів, в Англії - 25, Данії - 28, в більшості країн з розвиненим свинарством в 21 день [33, 38]. Тоді як в країнах $€ C$ законодавчо заборонено відлученВісник Сумського національного аграрного університету ня поросят раніш чотиритижневого віку[9].

Перевага раннього відлучення за твердженням $T$. Whiting та T. Pasma [41] полягає в тому, що воно завдяки скороченню відтворювального циклу дозволяє більш інтенсивно використовувати свиноматку, що в свою чергу забезпечує отримання від неї в більшої кількості поросят та раціональніше використовувати наявні виробничі площі найбільш дорогих відділень для опоросу.

Однак не існує єдиної думки що до віку відлучення поросят та його ефеективності. Так за твердженнями Г. М Седіло з співавторами [26], раннє відлучення поросят сприяє зменшенню кількісті захворювань виміні свиноматок, збільшує ефрективність використання профрілактичних та лікувальних засобів, скорочує необхідність у приміщеннях для прийому опоросів. На думку Г. С Походні з колегами [24] скорочення терміну підсисного періоду сприяє підвищенню рентабельності виробництва свинини в умовах промислового виробництва, але впливає на ріст і збереженість поголів'я поросят. За повідомленнями $€$. А. Козиної [11] кращою тривалістю підсисного періоду є 21 доба, за якої свиноматки майже не втрачають своєї вгодованості, тоді як поросята раніше привчаються до поїдання комбікормів, що сприяє більш інтенсивному розвитку їх травної системи, і як наслідок підвищенню енергії їх росту. Цю думку підтверджує П.П Антоненко з колегами [1] який вважає, що поросята за раннього відлучення починають раніше споживати рослинну їжу i, як наслідок, у них підвищуються середньодобові прирости живої маси при зниженні собівартості корму. За твердженням Г.С. Походні з співавторами [24], найдоцільнішим $€$ їх відлучення у віці $21-28$ доби. Водночас дослідженнях $€$. В 
Творогової [29] встановлено, що зниження тривалості лактації з 30 до 17 днів не впливає на кількість поросят, отриманих від однієї свиноматки в рік, а застосування раннього відлучення поросят дає змогу отримувати від кожної свиноматки 2,5 - 2,68 опороси на рік. В свою чергу як повідомляє В.И Ленина [13] та Е. В. Творогова [29], тривалий підсисний період веде до виснаження маток і погіршення їх відтворювальних якостей в порівнянні з раннім відлученням поросят. Ними встановлено, що зменшення тривалості лактації супроводжується збереженням маси тіла свиноматки. Раннє відлучення поросят на думку Н.И. Жирникова [10] та Л.Х Христофора [30] надає змогу здійснити більш раннє осіменіння для отримання наступного опоросу, що надає можливість отримувати більше поросят від кожної свиноматки в рік.

Але поряд з перевагами раннього відлучення поросят вченими вказується і на їх недоліки. Так на думку Jarvis S [33] відлучення поросят на промислових комплексах у віці 2-3 тижнів, через зміну місця утримання, утворення нової ієрархічної структури, перехід від вживання молока до вживання штучних кормів викликає у них стресовий стан, в результаті чого тварини певний час відмовляються від корму. Це призводить, на думку V.D Leibbrandt [36] до того, що поросята недоотримають потрібну для їх нормальної життєдіяльності кількість енергії і сповільнюють свій ріст. Водночас за даними досліджень J. M. Campbell et.all [32] незалежно від віку відлучення поросята втрачають в перший день після відлучення 100-250 г живої маси і відновлюють цю втрату лише на четвертий день. Аналогічних висновків досяг в свої дослідах М. В. Кузьменко [12] який вважає, що не залежно від тривалості підсисного періоду поросята переходять на повноцінне споживання сухого корму лише під кінець першого тижня дорощування. скорочення підсисного періоду до 3 тижнів $є$ ще одним фактором ризику для життя свиноматки і вимагає розробки спеціальних заходів і досконалого менеджменту [37].

Поряд з інтенсивністю використання свиноматок важливим $€$ їх продуктивне довголіття, яке на думку багатьох дослідників залежить від інтенсивності використання тварин. Так на думку В. А Стрельцова та В.В. Лаврова [28] скорочення підсисного періоду негативно впливає на тривалість використання свиноматок. Так за тривалості підсисного періоду від 17 до 21 днів їх вибракування виявилося майже в два рази більшим, ніж при відлученні поросят в 28 діб. Водночас О.В. Руковицан [25] вказує, що ефективність використання свиноматок залежить від тривалості їх репродуктивного життя, а рівень відтворювальних якостей збільшується при кожному наступному репродуктивному циклі включаючи восьмий. Дослідженнями D. Knecht [34], встановлено, що найгірші показники відтворювальної продуктивності були у свиноматок при першому їх опоросі, а найкращі на 3-му та 4-му. Також на вплив віку свиноматок на їх продуктивність вказують Н.А. Піотрович [19], С.І. Луговий [14] які зазначають найкращий її прояв за третього-п'ятого репродуктивного циклу.

Також важливим фактором який впливає на відтворювальну продуктивність свиноматок $€$ сезонність. У своїх дослідженнях М. Г. Повод та його колеги [21, 22] прийшли висновку, що кращу багатоплідність на 0,4 - 0,7 поросяти мають свиноматки опороси яких проходили взимку, порівняно $з$ іншими порами року. У той же час, влітку, спостеріга- лась найгірша збереженість поросят 73,2\% i, як наслідок, найменша їх кількість 10,8 голів в цю пору року виявилась на дату відлучення. Тоді як кращою збереженість поросят виявилась навесні 84,2\%. На думки Л. А. Гераніної [8] кращу багатоплідність, масу гнізда при народженні та кількість поросят при відлученні мали свиноматки в яких опороси проходили в весняний період. Тоді як за повідомленнями О. О. Стародубець [27] опороси у літньо - осінні місяці дозволили отримати в середньому 10,8 голів поросят на опорос, на відміну від інших місяців де цей показник був на рівні 9,9 - 10,6 голів поросят.

За різних термінів відлучення, важливим фрактором $€$ генотип використовуваних свиней та методи їх розведення. Так у своїх дослідженнях S. Ushakova [40] дійшла висновку, що при схрещуванні помісних маток великої білої та ландрас порід з помісними кнурами пєтренхдюрок та дюрокхпєтрен поросята перевершують чистопородних аналогів великої білої породи за масою гнізда на час відлучення на 5,1 і 0,06 кг відповідно.

При порівнянні двопородного схрещуванні свиней великої білої породи з кнурами породи ландрасами голландської та ірландської селекції проведеного Ж. А Перевойко [17] кращими виявилися помісі від першого поєднання, при якому, багатоплідність свиноматок склала 10,8 голови, а кількість поросят на час відлучення - 10,2 голови, тоді як, за чистопородного розведення великої білої породи багатоплідність становила - 11,7 голови, при 10,2 голови кількості відлучених поросят. За показником збереженості гіршими на $1,6-7,7 \%$ були гнізда свиней за чистопородного розведення. Для поліпшення відтворювальних якостей свиноматок А. N. Lazarevich [35] рекомендує використовувати поєднання свиней $F_{1}$ велика білахландрас з кнурами термінальних ліній PIC 731, маса яких при відлученні була на 22,2\% більшою у порівнянні з аналогами від схрещування порід йоркширхландрас.

В доступній нам літературі описані окремий вплив кожного із досліджуваних факторів на ознаки відтворювальної здатності. Але нами не знайдено публікацій по визначенню сили впливу чотирьох досліджуваних нами факторів на ці ознаки. Тому нами поставлено за мету і проведено дослідження впливу факторів тривалості підсисного періоду, віку та породних поєднань свиноматок в різні пори року на основні показники відтворювальної здатності.

Матеріали та методи досліджень. Дослідження проводилося впродовж 2018-2019 років на базі репродукторів № 1 і 2 ТОВ «НВП «Глобинський свинокомплекс». Для визначення впливу факторів тривалості підсипного періоду, віку свиноматок, їх породного поєднання та пори року нам було проведено чотирьохфакторний дисперсійний аналіз продуктивності двопородних свиноматок від ірландської великої білої та ландрас порід за прямого та реципрокного

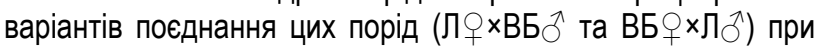
осіменінні їх спермою термінальних кнурів синтетичної лінії MaxGro . Всього було оброблено дані 3061 опоросу.

На репродукторі № 1 відлучення поросят від свиноматок відбувалось впродовж останніх трьох років в віці 21 доба, тоді як на аналогічному за розмірами та технологією репродукторі № 2 тривалість підсисного періоду складала 28 діб.

В холостий та умовно поросний період свиноматки на обох репродукторах утримувались в ідентичних індивідуВісник Сумського національного аграрного університету 
альних станках розміром 0,7 на 2,4 м на частково щілинній бетонній підлозі з нормованою годівлею, яка регулювалась за допомогою об'ємних дозаторів корму. Напування свиноматок здійснювалось з напувалок сталого рівня. На обох свинокомплексах підтримання параметрів мікроклімату здійснювалось за допомогою автоматичної системи вентиляції, кондиціонування та підігріву повітря фрірми Big Dutchman. Ця система негативного тиску була ідентичною для даної технологічної групи свиноматок на обох комплекcax.

Утримання свиноматок з встановленою поросністю відбувалось в окремих приміщеннях, стабільними групами по 60 голів, на повністю щілинній бетонній підлозі, з нормованою годівлею за допомогою кормових станцій Calmatic фірми Big Dutchman. Система вентиляції в приміщеннях для цієї технологічної групи, була аналогічною для обох комплексів і схожою з приміщеннями для умовнопоросних свиноматок.

Підсисні свиноматки з поросятами на обох підрозділах утримувались в окремих секціях по 60 голів в кожній, в індивідуальних станках розміром 1,8 на 2,4 м, на повністю щілинній підлозі, чавунній для свиноматок і полімерній для поросят. 3 метою створення локального мікроклімату для поросят кожен станок був обладнаний водяним килимком підігріву та інфрачервоною лампою. Годівля свиноматок 3 другого дня лактації здійснювалась вволю, за допомогою індивідуальних дозаторів корму Sowmax фрірми Hog Slat Україна.

Їх напування проводилось 3 індивідуальної ніпельної автонапувалки, розташованою біля годівниці.

Підгодівля поросят здійснювалась за допомогою з'ємної круглої годівниці, яка закріплювалась на решітчасту підлогу, а напування з мисочкової автонапувалки розташованої в тильній частині станка.

Годівля свиноматок та поросят була повноцінною та збалансованою, комбікормами відповідних рецептур, які виготовлялись на власному комбікормовому заводі. Підгодівля поросят обох груп здійснювалась 37 доби життя пре- стартерними кормами компанії Cargil.

В дослідженнях враховувались наступні показники: загальна кількість поросят при народженні (потенційна багатоплідність), кількість живих поросят при народжені (багатоплідність), маса гнізда при народженні, великоплідність, збереженість поросят до відлучення та їх кількість і маса гнізда на цей час.

Шляхом чотирифакторного дисперсійного аналізу визначали силу впливу віку свиноматок та тривалості підсисного періоду на зміни вище перерахованих показників відтворювальних якостей свиноматок.

Експериментальні дані оброблені методом варіаційної статистики за Н.А. Плохинским $[19,20]$ із використанням комп'ютерної техніки та пакетів прикладного програмного забезпечення MS Excel 2013 та Statistika V.10.0.

Вірогідність різниці між тваринами кожної піддослідної групи за окремими ознаками встановлювали за допомогою таблиці стандартного значення Ст'юдента-Фішера, описаного І. А. Ойвіним (1960). В дослідженнях прийнята наступна система імовірності: $p<0,05 ; p<0,01 ; p<0,001$.

Результати досліджень. Для визначення сили впливу тривалості лактації, пори року, віку свиноматок, їх породних поєднань та взаємодії на вище перерахованих фракторів на зміну окремих показників відтворювальної продуктивності свиноматок нам було проведено чотирифакторний дисперсійний аналіз. За результатами розрахунків встановлено достовірний вплив віку свиноматок на кількість поросят при народжені на рівні 1,7\% (p<0,05) (рис.1). Решта досліджуваних факторів не мали достовірного впливу на кількість поросят при народжені. Дія неврахованих факторів становила - $87,8 \%$.

При визначені сили впливу досліджуваних факторів на багатоплідність свиноматок, (рис. 2), було встановлено достовірний вплив з силою 2,2\% (p<0,01) на цю ознаку лише віку свиноматок. Інші досліджувані фрактори не мали достовірного впливу. Дія неврахованих фракторів становила $86,8 \%$. 
- Сезон року

๑ Тривалість підсисного періоду

๑ Репродуктивний цикл

в Варіант поєднання породи

๑ Взаємодія сезону року та тривалості підсисного періоду

$\square$ Взаємодія сезону року та репродуктивного циклу

๑ Взаємодія тривалості підсисного періоду та репродуктивного циклу

— Взаємодія сезону року та варіану поєднання породи

$\square$ Взаємодія тривалості підсисного періоду та варіанту поєднання породи

口 Взаємодія репродуктивного циклу та варіанту поєднання породи

- Взаємодія сезону року, тривалості підсисного періоду та репродуктивного циклу

$\square$ Взаємодія сезону року, тривалості підсисного періоду та варіанту поєднання породи

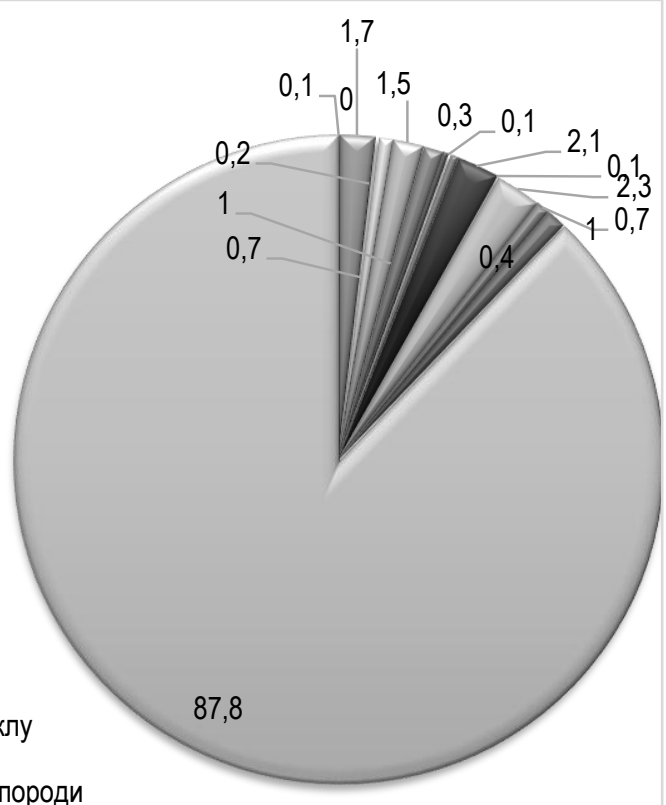

๑ Взаємодія сезону року, репродуктивного циклу та варіанту поєднання породи

В Взаємодія тривалості підсисного періоду, репродуктивного циклу та варіанту поєднання породи

口 Взаємодія досліджуваних факторів

$\square$ Дія неврахованих фракторів

\section{Рис. 1. Сила впливу досліджуваних факторів на кількість поросят при народженні,\%}

\section{- Сезон року}

๑ Тривалість підсисного періоду

$\square$ Репродуктивний цикл

• Варіант поєднання породи

$\square$ Взаємодія сезону року та тривалості підсисного періоду

๑ Взаємодія сезону року та репродуктивного циклу

Взаємодія тривалості підсисного періоду та репродуктивного циклу

口 Взаємодія сезону року та варіану поєднання породи

๑ Взаємодія тривалості підсисного періоду та варіанту поєднання породи

口 Взаємодія репродуктивного циклу та варіанту поєднання породи

• Взаємодія сезону року, тривалості підсисного періоду та репродуктивного циклу

$\square$ Взаємодія сезону року, тривалості підсисного періоду та варіанту поєднання породи

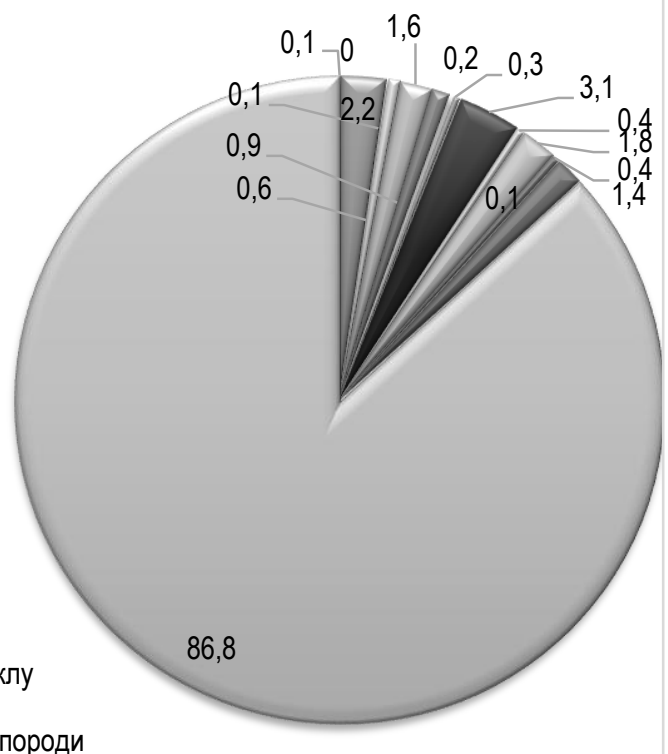

๑ Взаємодія сезону року, репродуктивного циклу та варіанту поєднання породи

๑ Взаємодія тривалості підсисного періоду, репродуктивного циклу та варіанту поєднання породи

口 Взаємодія досліджуваних факторів

$\square$ Дія неврахованих факторів

\section{Рис. 2. Сила впливу досліджуваних ффакторів на багатоплідність свиноматок,\%}

Встановлено достовірний вплив на масу гнізда поро- | сят при народженні: - тривалості підсисного періоду - 1,9\% 
( $<<0,001)$; віку свиноматок - 2,3\% ( $p<0,01)$; взаємодії пори року, тривалості підсисного періоду та віку свиноматок $3,2 \%(p<0,05)$ (рис. 3). Дія неврахованих факторів становила
- 84,6\%. Тоді як інші досліджувані фактори не мали достовірного впливу.

- Сезон року

๑Тривалість підсисного періоду

๑Репродуктивний цикл

• Варіант поєднання породи

$\square$ Взаємодія сезону року та тривалості підсисного періоду

๑Взаємодія сезону року та репродуктивного циклу

$\square$ Взаємодія тривалості підсисного періоду та репродуктивного циклу

■заємодія сезону року та варіану поєднання породи

$\square$ Взаємодія тривалості підсисного періоду та варіанту поєднання породи

■ Взаємодія репродуктивного циклу та варіанту поєднання породи

в Взаємодія сезону року, тривалості підсисного періоду та репродуктивного циклу

$\square$ Взаємодія сезону року, тривалості підсисного періоду та варіанту поєднання породи

$\square$ Взаємодія сезону року, репродуктивного циклу та варіанту поєднання породи

๑ Взаємодія тривалості підсисного періоду, репродуктивного циклу та варіанту поєднання породи

•Взаємодія досліджуваних факторів

$\square$ Дія неврахованих фракторів

\section{Рис. 3. Сила впливу досліджуваних факторів на масу гнізда поросят при народженні,\%}

Досліджуючи силу впливу тривалості лактації, пори року, віку свиноматок, їх породних поєднань на кількість поросят при відлученні (рис.4) встановлено достовірний вплив на рівень змін цієї ознаки: віку свиноматок на $8,3 \%$ ( $p<0,001) ;$ пори року на 1,6\% ( $p<0,01) ;$ тривалості підсисного періоду - 0,4\% (p<0,05); взаємодії пори року та віку свиноматок - 8,1\% (р<0,001); взаємодія тривалості підсисного періоду та віку свиноматки - 2,6\% ( $<<0,001)$; взаємодії пори року, тривалості підсисного періоду та віку свиноматки $5,9 \%(p<0,001)$.

Водночас інші досліджувані фрактори не мали досто- вірного впливу, а дія неврахованих фракторів склала $69,7 \%$.

За результатами дослідження сили впливу вищезазначених факторів на збереженість поросят (рис. 5) встановлено достовірний вплив віку свиноматок на рівень прояву цієї ознаки як 6,7\% (p<0,001); тривалості підсисного періоду - 0,8\% (p<0,01); пори року на рівні 2,1\% ( $<<0,001)$; взаємодії пори року та віку свиноматки - 3,5\% ( $<<0,05)$. Дія фракторів які нами не враховувались клала - 80,1\%, тоді як решта досліджуваних факторі і їх взаємодія мають недостовірний вплив. 
- Сезон року

口Тривалість підсисного періоду

๑Репродуктивний цикл

• Варіант поєднання породи

๑ Взаємодія сезону року та тривалості підсисного періоду

๑ Взаємодія сезону року та репродуктивного циклу

口 Взаємодія тривалості підсисного періоду та репродуктивного циклу

口Взаємодія сезону року та варіану поєднання породи

๑ Взаємодія тривалості підсисного періоду та варіанту поєднання породи

口Взаємодія репродуктивного циклу та варіанту поєднання породи

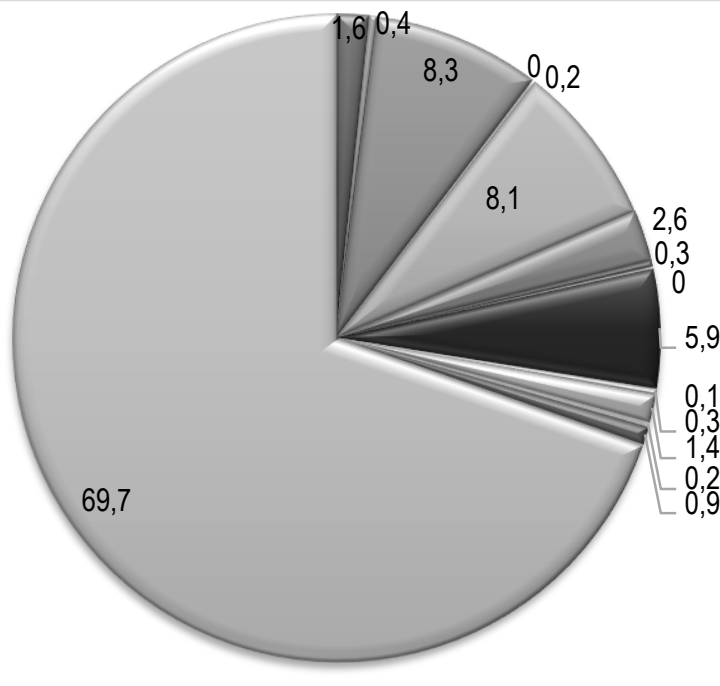

- Взаємодія сезону року, тривалості підсисного періоду та репродуктивного циклу

๑Взаємодія сезону року, тривалості підсисного періоду та варіанту поєднання породи

๑ Взаємодія сезону року, репродуктивного циклу та варіанту поєднання породи

口 Взаємодія тривалості підсисного періоду, репродуктивного циклу та варіанту поєднання породи

• Взаємодія досліджуваних факторів

๑Дія неврахованих фракторів

Рис. 4. Сила впливу досліджуваних факторів на кількість поросят при відлученні,\%

$\square$ - Сезон року

๑Тривалість підсисного періоду

๑Репродуктивний цикл

曰 Варіант поєднання породи

$\square$ Взаємодія сезону року та тривалості підсисного періоду

$\square$ Взаємодія сезону року та репродуктивного циклу

口Взаємодія тривалості підсисного періоду та репродуктивного циклу

• Взаємодія сезону року та варіану поєднання породи

ஐВзаємодія тривалості підсисного періоду та варіанту поєднання породи

口Взаємодія репродуктивного циклу та варіанту поєднання породи

- Взаємодія сезону року, тривалості підсисного періоду та репродуктивного циклу

$\square$ Взаємодія сезону року, тривалості підсисного періоду та варіанту поєднання породи

$\square$ Взаємодія сезону року, репродуктивного циклу та варіанту поєднання породи

$\square$ Взаємодія тривалості підсисного періоду, репродуктивного циклу та варіанту поєднання породи

•Взаємодія досліджуваних факторів

$\square$ Дія неврахованих факторів

\section{Рис. 5. Сила впливу досліджуваних фракторів на збереженість поросят,\%}

При визначені сили впливу тривалості лактації, пори року, віку свиноматок та їх породних поєднань на середню масу одного поросяти при відлученні які зображено на (рис. 6) встановлено достовірний вплив тривалості підсисного Вісник Сумського національного аграрного університету 
періоду - 64,4\% (p<0,001); пори року на рівні 0,5\% ( $p<0,01)$; віку свиноматки - 1,9\% ( $<<0,001)$; взаємодії пори року та тривалості підсисного періоду - 3,1\% (p<0,001); взаємодія пори року та віку свиноматки Водночас інші досліджувані фактори мали недостовірного впливу, а дія неврахованих факторів становила $-24,9 \%$.

$\square$ Сезон року

$\square$ Тривалість підсисного періоду

๑Репродуктивний цикл

в Варіант поєднання породи

$\square$ Взаємодія сезону року та тривалості підсисного періоду

口Взаємодія сезону року та репродуктивного циклу

口Взаємодія тривалості підсисного періоду та репродуктивного циклу

口Взаємодія сезону року та варіану поєднання породи

๑Взаємодія тривалості підсисного періоду та варіанту поєднання породи

口Взаємодія репродуктивного циклу та варіанту поєднання породи

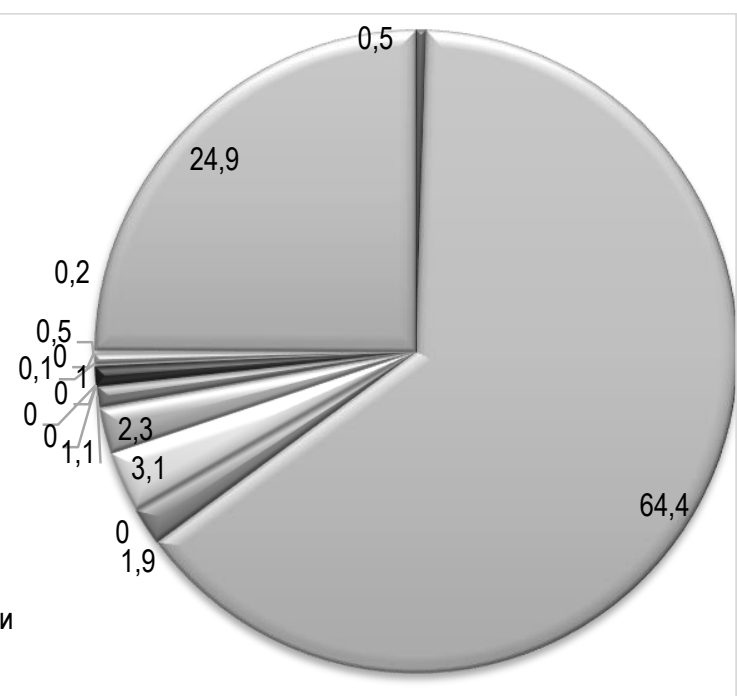

- Взаємодія сезону року, тривалості підсисного періоду та репродуктивного циклу

๑заємодія сезону року, тривалості підсисного періоду та варіанту поєднання породи

$\square$ Взаємодія сезону року, репродуктивного циклу та варіанту поєднання породи

口Взаємодія тривалості підсисного періоду, репродуктивного циклу та варіанту поєднання породи

•Взаємодія досліджуваних факторів

$\square$ Дія неврахованих фракторів

\section{Рис. 6. Сила впливу досліджуваних факторів на середню масу одного поросяти при відлученні,\%}

За даними вивчення чотирьох досліджуваних факторів на масу гнізда поросят при відлученні (рис. 7) було встановлено достовірний вплив тривалості підсисного періоду на рівень прояву вказаної ознаки з силою 73,0\% (p<0,001); пори року на рівні $0,4 \%$ ( $<<0,01)$; віку свиноматок - 0,6\% ( $<<0,01)$; взаємодії пори року та тривалості підсисного періоду - 4,3\% ( $<<0,001)$; взаємодії пори року, тривалості підсисного періоду та віку свиноматки - 0,9\% ( $p<0,01)$, тоді як інші досліджувані фрактори не мали достовірного впливу,а дія неврахованих фракторів склала - 18,7\%.
За допомогою чотирифакторного дисперсійного аналізу встановлено достовірний вплив на абсолютні прирости поросят (рис. 8): - тривалості підсисного періоду на рівні $63,0 \%$ ( $p<0,001)$; віку свиноматки - 2,0\% ( $<<0,001)$; пори року - 0,6\% (р<0,01); взаємодії пори року та тривалості підсисного періоду - 3,1\% ( $<<0,001)$; взаємодії пори року та віку свиноматки - 2,4\% ( $<<0,001)$; взаємодії тривалості підсисного періоду та віку свиноматки - 1,0\% ( $<0,001)$; взаємодії пори року, тривалості підсисного періоду та віку свиноматки 1,1\% $(p<0,05)$. 
- Сезон року

๑Тривалість підсисного періоду

๑Репродуктивний цикл

в Варіант поєднання породи

$\square$ Взаємодія сезону року та тривалості підсисного періоду

๑Взаємодія сезону року та репродуктивного циклу

๑ Взаємодія тривалості підсисного періоду та репродуктивного циклу

口Взаємодія сезону року та варіану поєднання породи

๑Взаємодія тривалості підсисного періоду та варіанту поєднання породи

•Взаємодія репродуктивного циклу та варіанту поєднання породи

- Взаємодія сезону року, тривалості підсисного періоду та репродуктивного циклу

$\square$ Взаємодія сезону року, тривалості підсисного періоду та варіанту поєднання породи

$\square$ Взаємодія сезону року, репродуктивного циклу та варіанту поєднання породи

口Взаємодія тривалості підсисного періоду, репродуктивного циклу та варіанту поєднання породи

口Взаємодія досліджуваних факторів

$\square$ Дія неврахованих факторів

\section{Рис. 7. Сила впливу досліджуваних фракторів на масу гнізда поросят при відлученні,\%}

口Тривалість підсисного періоду

๑Репродуктивний цикл

в Варіант поєднання породи

$\square$ Взаємодія сезону року та тривалості підсисного періоду

๑ Взаємодія сезону року та репродуктивного циклу

๑Взаємодія тривалості підсисного періоду та репродуктивного циклу

•Взаємодія сезону року та варіану поєднання породи

$\varpi$ Взаємодія тривалості підсисного періоду та варіанту поєднання породи

口Взаємодія репродуктивного циклу та варіанту поєднання породи

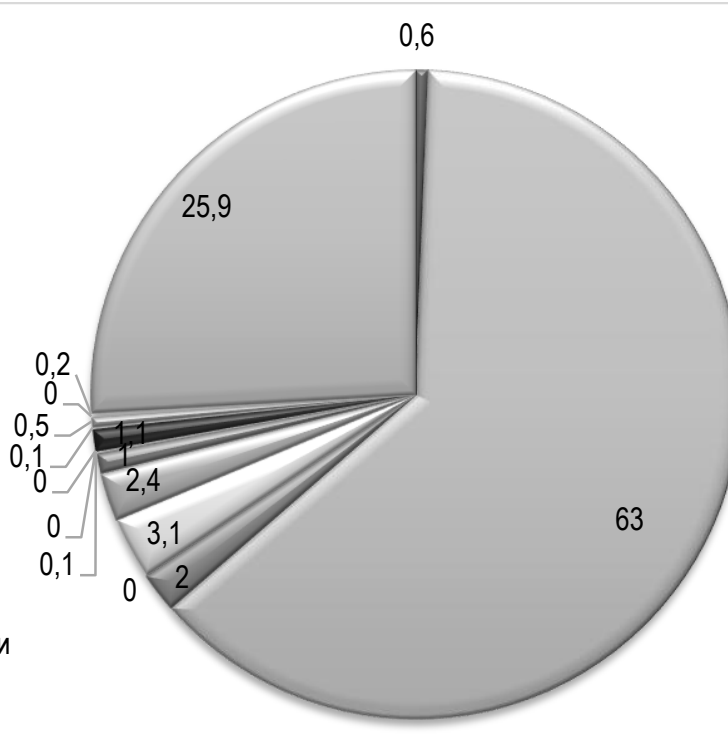

- Взаємодія сезону року, тривалості підсисного періоду та репродуктивного циклу

$\square$ Взаємодія сезону року, тривалості підсисного періоду та варіанту поєднання породи

口Взаємодія сезону року, репродуктивного циклу та варіанту поєднання породи

口Взаємодія тривалості підсисного періоду, репродуктивного циклу та варіанту поєднання породи

•Взаємодія досліджуваних факторів

$\nabla$ Дія неврахованих фракторів

Рис. 8. Сила впливу досліджуваних факторів на абсолютні прирости поросят в підсисний період ,\% 
Інші досліджувані фактори мали недостовірний вплив, а дія неврахованих фракторів склала $25,9 \%$.

При розрахунку сили впливу тривалості лактації, пори року, віку свиноматок та їх породних поєднань на середньодобові прирости поросят сисунів (рис.9) встановлено достовірний вплив тривалості підсисного періоду на рівні $8,4 \%$ ( $p<0,001)$; віку свиноматки - 4,5\% ( $p<0,001) ;$ пори року
$1,6 \%$ ( $p<0,001)$; взаємодії пори року та тривалості підсисного періоду $-8,2 \%$ ( $<<0,001)$; взаємодії пори року та віку свиноматки - 6,4\% ( $<<0,001)$; взаємодії тривалості підсисного періоду та віку свиноматки - 2\% (р p<0,001); взаємодії пори року, тривалості підсисного періоду та віку свиноматки $2,7 \%(p<0,05)$;

\section{曰 Сезон року}

๑ Тривалість підсисного періоду

๑ Репродуктивний цикл

- Варіант поєднання породи

$\square$ Взаємодія сезону року та тривалості підсисного періоду

๑ Взаємодія сезону року та репродуктивного циклу

口 Взаємодія тривалості підсисного періоду та репродуктивного циклу

• Взаємодія сезону року та варіану поєднання породи

๑ Взаємодія тривалості підсисного періоду та варіанту поєднання породи

口Взаємодія репродуктивного циклу та варіанту поєднання породи

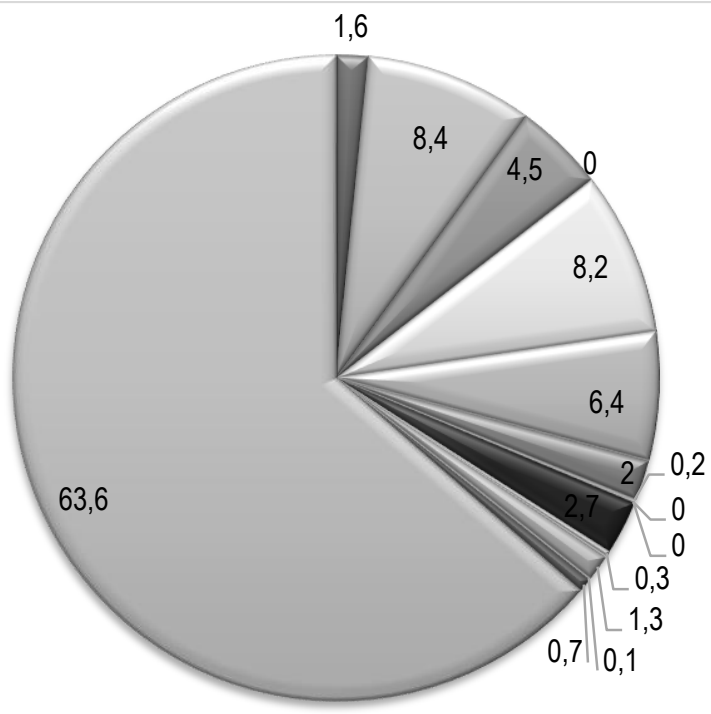

В Взаємодія сезону року, тривалості підсисного періоду та репродуктивного циклу

$\checkmark$ Взаємодія сезону року, тривалості підсисного періоду та варіанту поєднання породи

口Взаємодія сезону року, репродуктивного циклу та варіанту поєднання породи

口Взаємодія тривалості підсисного періоду, репродуктивного циклу та варіанту поєднання породи

口Взаємодія досліджуваних факторів

口 Дія неврахованих фракторів

\section{Рис. 9. Сила впливу досліджуваних факторів на середньодобові прирости поросят в підсисний період ,\%}

Інші досліджувані фрактори не мали достовірного впливу. Дія неврахованих фракторів становила 63,6\%.

За результатами розрахунку сили впливу досліджуваних фракторів на відносні прирости поросят сисунів ( рис 10) було встановлено достовірний вплив пори року на рівні $1,2 \%$ (р<0,001); тривалості підсисного періоду 55,8\% ( $<<0,001)$; віку свиноматок - 1,8\% ( $<<0,001)$; взаємодії сезону року та тривалості підсисного періоду - 3,2\% ( $p<0,001)$; взаємодії сезону року та репродуктивного циклу - 3,2\% ( $<<0,001)$; взаємодії тривалості підсисного періоду та репродуктивного циклу - 0,8\% ( $p<0,01)$; взаємодії сезону року, тривалості підсисного періоду та репродуктивного циклу
$1,4 \%$ ( $<0,01)$. Дія неврахованих фракторів склала $31 \%$.

Таким чином тривалість підсисного періоду найбільш суттєво впливає на масу гнізда поросят при відлучені 73,0\%, - середню масу одного поросяти при відлучені 64,4\%, - абсолютні прирости поросят в підсисний період $63,0 \%$, середньодобові прирости в цей період - 8,4\%. Цей фрактор також мав незначний, але вірогідний вплив на відносні прирости в підсисний період - 1,2\%, збереженість поросят до відлучення - 0,7\% і масу гнізда при народжені - 1,9\% та кількість поросят при відлучені - 0,4\%. Водночас цей фактор не мав впливу на загальну кількість поросят при народжені та багатоплідність свиноматок. 


\author{
$\square$ Сезон року \\ ๑ Тривалість підсисного періоду \\ ๑Репродуктивний цикл \\ в Варіант поєднання породи \\ $\square$ Взаємодія сезону року та тривалості підсисного періоду \\ ๑ Взаємодія сезону року та репродуктивного циклу
}

口 Взаємодія тривалості підсисного періоду та репродуктивного циклу

口 Взаємодія сезону року та варіану поєднання породи

口Взаємодія тривалості підсисного періоду та варіанту поєднання породи

$\square$ Взаємодія репродуктивного циклу та варіанту поєднання породи

- Взаємодія сезону року, тривалості підсисного періоду та репродуктивного циклу

๑ Взаємодія сезону року, тривалості підсисного періоду та варіанту поєднання породи

口Взаємодія сезону року, репродуктивного циклу та варіанту поєднання породи

口 Взаємодія тривалості підсисного періоду, репродуктивного циклу та варіанту поєднання породи

口Взаємодія досліджуваних факторів

$\square$ Дія неврахованих факторів

Рис. 10. Сила впливу досліджуваних факторів на відносні прирости поросят в підсисний період ,\%

Тоді як пора року мала значно менший вплив на досліджувані показники. Найбільш суттєво вона впливала на збереженість поросят до відлучення - 2,1\%, кількість поросят при відлучені та їх середньодобові прирости в підсисний період по 1,6\%, відносні прирости в цей період - 1,2\%. Менший, але вірогідний вплив пора року виявила на абсолютний приріст поросят в підсисний період - 0,6\%, масу одного поросяти та масу гнізда при відлучені - відповідно 0,5\% та 0,4\% і зовсім не вплинула на загальну кількість поросят при народжені, багатоплідність та масу гнізда поросят при народжені.

В свою чергу вік свиноматки мав вірогідний вплив на всі досліджувані показники. Найбільший вплив він спричинив на кількість поросят при відлучені - 8,3\%, їх збереженість до відлучення - 6,7\%, середньодобові прирости в підсисний період - 4,5\%, масу гнізда поросят при народжені - 2,3\% і багатоплідність свиноматок -2,2\%. Дещо нижчим, але вірогідним, виявився вплив віку свиноматок на абсолютний приріст поросят в підсисний період 2,0\%, масу одного поросяти та масу гнізда при відлучені $-1,9 \%$, на загальну кількість поросят при народжені - 1,7\%, відносний приріст поросят в підсисний період - 1,2\%. Найменший влив цей фрактор мав на масу гнізда поросят при відлучені - 0,6\%.

Водночас породні поєднання свиноматок ЛохВБ今 та ВБ $\propto \times Л \widehat{\jmath}$ не мали вірогідного впливу на показники відтворювальної здатності, що вивчались.
Висновки. Найбільш суттєвий вплив тривалості підсисного періоду встановлено на масу гнізда поросят при відлучені - 73,0\%, - середню масу одного поросяти при відлучені - 64,4\%, - абсолютні прирости поросят в підсисний період - 63,0\%, середньодобові прирости в цей період $8,4 \%$ тоді як він не впливав на загальну кількість поросят при народжені та багатоплідність свиноматок.

Вплив пори року вірогідно становив - на збереженість поросят до відлучення - 2,1\%, кількість поросят при відлучені та їх середньодобові прирости в підсисний період по 1,6\%, відносні прирости в цей період - 1,2\%. і зовсім не впливав на загальну кількість поросят при народжені, багатоплідність та масу гнізда поросят при народжені.

Вік свиноматки мав вірогідний вплив на всі досліджувані показники і становив - на кількість поросят при відлучені - 8,3\%, їх збереженість до відлучення - 6,7\%, середньодобові прирости в підсисний період - 4,5\%, масу гнізда поросят при народжені - 2,3\% і багатоплідність свиноматок -2,2\%, на абсолютний приріст поросят в підсисний період 2,0\%, масу одного поросяти та масу гнізда при відлучені -1,9\%, на загальну кількість поросят при народжені - 1,7\%, відносний приріст поросят в підсисний період - 1,2\%, на масу гнізда поросят при відлучені - 0,6\%.

Породні поєднання свиноматок ЛохВБ今 та ВБ $\odot \times Л \widehat{\jmath}$ не мали вірогідного впливу на досліджувані показники відтворювальної здатності.

\title{
Список використаної літератури:
}

1.Антоненко П. П., Свежицев Д. Н. Масляк и др. Нормированое кормление свиней. Д. : Арт-Пресс, 2009. 360 с.

2.Баньковська І. Б., Волощук В. М., Подобєд Л. І., Смислов, С. Ю. Модель оптимізації виробництва якісної свинини в сучасних умовах товарного свинарства. Науковий вісник Національного університету біоресурсів і природокористування України. Серія: Технологія виробництва і переробки продукції тваринництва. 2016. Вип. 250, С. 114-124. 
3.Близнецов А. В. Результативность скрещивания свиней при разных типах кормления. Зоотехния. 2002. № 8, С. 23-25.

4. Виноградський А. І. Раннє відлучення поросят. К. : Урожай, 1975. 64 с.

5.Власов В. І., Ткач Г. В. Глобалізація і мальтузіанство. Економіка АПК. 2005. №9 (131), С. 9-15.

6.Волощук В. М. Особливості селекційно-технологічних рішень та організаційних форм у сучасному свинарстві. Свинарство. 2012. №. 61, С. 3-8.

7.Волощук В. М., Рибалко В. П., Березовський М. Д. та ін. Свинарство : монографія. К. : Аграрна наука, 2014. 587 с.

8.Гераніна Л. А. Взаємозв'язок між багатоплідністю свиноматок і ростом поросят у різні сезони року. Свинарство. 2016. Вип. 68. С. 59-63.

9.Гетя А. А. Організація селекційного прогресу в сучасному свинарстві: Монографрія. Полтава: Полтавський літератор, 2009. $192 \mathrm{c}$.

10.Жирников Н. И. Влияние различных сроков отъема поросят на репродуктивные качества маток, рост и развитие приплода. Известия Оренбургского государственного аграрного университета. 2008. № 1(17), C. 84-86.

11.Козина Е. А., Жемер Ю. А. Рост и сохранность поросят при разных сроках отъема. Актуальные направления фрундаментальных и прикладных исследований. 2019, С. 18-21.

12.Кузьменко М.В.Ефективність відгодівлі молодняку свиней за різної початкової маси. Вісник аграрної науки. 2012. №. 12, C. $77-78$

13.Ленина В. И. Повышение эффективности использования маточного стада свиней. Всесоюзн. Акад. с.-х. наук им. В. И. Ленина. М: Колос, 1983. 179 с.

14.Луговий С. І., Лихач В. Я. Влияние возраста двухпородных свиноматок на их воспроизводительные качества. Технологія виробництва і переробки продукції тваринництва : зб. наук. праць Білоцерк. національний аграр. ун-т. Біла церква. 2015. Вип. 1(116), С. 45-49.

15.Морару И., Фогльмайр Т., Грисслер А. и др. Энциклопедия воспроизводства. К. : Рема-Принт, 2012. 225 с.

16. Немченко В. В. Продовольча безпека України. Збірник наукових праць ВНАУ. 2012. Т. 2. №. 4, С. 70.

17.Перевойко Ж, А., Косилов В. И. Воспроизводительная способность свиноматок крупной белой породы и её двухтрёхпородных помесей. Известия Оренбургского государственного аграрного университета. 2014. Вып. 6, С. 161 - 163.

18.Піотрович Н. А. Формування відтворювальних якостей свиноматок та оцінка їх комбінаційної здатності. Автореферат дисертації. Миколаїв, 2017. с. 14

19.Плохинский Н. А. Биометрия. М. : Моск. ун-т, 1970. 366 с.

20.Плохинский Н. А. Руководство по биометрии для зоотехников. М. : Колос, 1969. 256 с.

21.Повод М. Г., Корж О. В., Нестеров А. М. Вплив пори року на відтворні якості свиноматок данської селекції. Вісник Сумського національного аграрного університету. Серія: Тваринництво.2017. Вип. 5 (2), С. 111-113.

22.Повод М. Г. Поведінка та продуктивність підсисних свиноматок впродовж року за різних умов утримання. Технологія виробництва і переробки продукції тваринництва. 2015 Вип. 2, С. 35 - 41.

23.Польовий Л. В., Кульчицька А. П. Формування м'ясної продуктивності та економічна ефективність виробництва свинини залежно від тривалості підсисного періоду. Вісник аграрна наука та харчові технології. 2017. Вип. 4 (98), С. 190191.

24.Походня Г. С., Корниенко П. П., Малахова Т. А. Кренева Т. В., Маменко А. М. Эффективность выращивания поросят при различных сроках их отъёма. Проблеми зооінженерії та ветеринарної медицини. 2017. Вып. 33. Ч. 1, С. $129-134$.

25.Руковицан О. В. Вплив порядкового номеру опоросу на продуктивність свиноматок великої білої породи. Студентський науковий вісник МНАУ. 2018. С. 243-249.

26.Седіло Г. М., Пундик В. П., Каплінський В. В., Тесак Г. В. Раннє відлучення поросят: переваги та проблеми. Збірник наукових праць Інституту сільського господарства Карпатського регіону НААН. Передгірне та гірське землеробство $і$ тваринництво. 2013. Вип. 55 (II), С. 176-177.

27.Стародубець О. О., Стародубець А. А. Вплив сезону року на відтворювальні якості свиноматок. Вісник аграрної науки Причорномор'я. 2015. Вип. 2 (84). Т. 2, С. 100 - 104.

28.Стрельцов В. А., Лавров В .В. Естественная резистентность у поросят при различных сроках отъема.Материаль Международной научно-практической конференции, посвященной 75-летию со дня рождения и 50-летию трудовой деятельности Заслуженного деятеля науки РФ, Заслуженного ученого Брянской области, Почетного профрессора Брянского ГАУ, доктора сельскохозяйственных наук, профессора Гамко Леонида Никифоровича. 2016, с. 280-283.

29.Творогова Е. В. Экономические предпосылки внедрения технологии сверхраннего отъема поросят. Вестник Чувашского государственного педагогического университета им. И. Я Яковлева. 2013. № 2 (78). С. 159-162

30.Христофор Л. Х. Влияние срока отъема поросят на продуктивность и воспроизводительные качества св иноматок в условиях Якутии: автореф. дис. на здобуття наук. ступеня канд. с.-г. наук: спец. 06.02.04 "Ветеринарная хирургия. Якут. гос. с.-х. акад., 2006. 19 с.

31.Черненко А. В. Вплив способу утримання свиноматок на продуктивні якості свиней різних генотипів : дис. кандидата с.-г. наук : 06.02.04. Херсон, 2008. 166 c.

32.Campbell J. M., Crenshaw J. D., Polo J. The biological stress of early weaned piglets. Journal of animal science and biotechnology. 2013. issue 1, P. 19.

33.Jarvis S., et al. Effects of weaning age on the behavioural and neuroendocrine development of piglets. Applied Animal Behaviour Science. 2008. Issue 1, P. 166-181.

Вісник Сумського національного аграрного університету 
34.Knecht D., Srodon S., and Duzinski K. The impact of season, parity and breed on selected reproductive performance parameters of sows. Arch. Anim. Breed. 2015. issue 58, PP. 49-56

35.Lazarevich A.N., Efimova L.V., Ivanova O.V. Effectiveness analysis of crossbreding the hybrid sows with thoroughbred and terminal sires. In the World of Scientific Discoveries, Series B. 2017. issue 2, P. 16-32.

36.Leibbrandt V. D., Ewan J. R.C., Zimmerman D.R. Effect of weaning and age at weaning on baby pig performance. Anim. Sci. 1975. issue 40, pp. 1077-1080.

37.Marin D. Nursing management and its impact on weaned piglet weight. Porcine Research. 2012. vol. 2, issue 1, pp. 23-26.

38.Peet B. Is it time to re-assess your weaning age? [electronic resource] Western Hog Journal.-Sheffield: Benchmark House, February, 2003. Access mode: www.thepigsite.com/articles/807/is-it-timeto-reassess-your-weaning-age

39.Turpin D. L, Langendijk P, Chen T. Y, Pluske J. R. Intermittent Suckling in Combination with an Older Weaning Age Improves Growth, Feed Intake and Aspects of Gastrointestinal Tract Carbohydrate Absorption in Pigs after Weaning. Animals (Basel). 2016;6(11):66. Published 2016 Oct 25. doi:10.3390/ani6110066.

40.Ushakova S. Influence of boars of different breeds on reproductive qualities of sows in multipedigree crossbreeding. Visnyk Agrarnoi Nauky. 2016. issue. 94 (2), P. 68-69.

41.Whiting T., Pasma T. Isolated weaning technology: humane benefits and concerns in the production of pork. The Canadian veterinary journal. 2008. issue 49, pp. 293-301.

\section{References:}

1. Antonenko, P. P., Svezhicev, D. N., Masljak et al., 2009. Normirovanoe kormlenie svinej [Rationed feeding of pigs]. D. : Art-Press.

2. Ban'kovs'ka, I. B., Voloshhuk, V. M., Podobjed, L. I. and Smyslov, S. Ju., 2016. Model' optymizacii' vyrobnyctva jakisnoi' svynyny v suchasnyh umovah tovarnogo svynarstva[Model of optimization of quality pork production in modern conditions of commercial pig breeding]. Naukovyj visnyk Nacional'nogo universytetu bioresursiv i pryrodokorystuvannja Ukrai'ny. Serija: Tehnologija vyrobnyctva i pererobky produkcii' tvarynnyctva, issue. 250, pp. 114-124.

3. Bliznecov, A. V., 2002. Rezul'tativnost' skreshhivanija svinej pri raznyh tipah kormlenija [Efficiency of crossing pigs with different types of feeding]. Zootehnija, issue 8,pp. 23-25.

4. Vinograds'kij, A. I., 1975. Ranne vidluchennja porosjat [Early admission of piglets]. K. : Urozhaj.

5. Vlasov, V. I. and Tkach, G. V., 2005. Globalizacija i mal'tuzianstvo [Globalization and Malthusianism]. Ekonomika APK, issue 9 (131), pp. 9-15.

6. Voloshhuk, V. M., 2012. Osoblyvosti selekcijno-tehnologichnyh rishen' ta organizacijnyh form u suchasnomu svynarstvi [Features of selection and technological solutions and organizational forms in modern pig breeding]. Svynarstvo, issue 61, pp. 3-8.

7. Voloshhuk V. M., Rybalko V. P., Berezovs'kyji M. D. et al., 2014. Svynarstvo: monografija. K. : Agrarna nauka.

8. Geranina, L. A., 2016. Vzajemozv'jazok mizh bagatoplidnistju svynomatok i rostom porosjat u rizni sezony roku [The relationship between the fertility of sows and the growth of piglets in different seasons]. Svynarstvo, 2016. vol. 68, pp. 59-63.

9. Getja, A. A., 2009. Organizacija selekcijnogo progresu v suchasnomu svynarstvi [Organization of selection progress in modern pig breeding]. monografija. Poltava: Poltavs'kyj literator, $192 \mathrm{p}$.

10. Zhyrnykov, N. Y., 2008. Vlyjanye razlychnыh srokov otъema porosjat na reproduktyvnыe kachestva matok, rost y razvytye pryploda [Influence of different weaning times of piglets on reproductive qualities of queens, growth and development of offspring]. Yzvestyja Orenburgskogo gosudarstvennogo agrarnogo unyversyteta, issue 1(17), pp. 84-86.

11. Kozina, E. A. and Zhemer, Ju. A., 2019. Rost i sohrannost' porosjat pri raznyh srokah otema [Growth and safety of piglets at different weaning dates]. Aktual'nye napravlenija fundamental'nyh i prikladnyh issledovanij, pp. 18-21.

12. Kuz'menko, M. V., 2012. Efektyvnist' vidgodivli molodnjaku svynej za riznoi' pochatkovoi' masy [Efficiency of fattening young pigs at different initial weight]. Visnyk agrarnoi' nauky, issue 12, pp. 77-78

13. Lenina, V. I., 1983. Povyshenie jeffektivnosti ispol'zovanija matochnogo stada svinej. Vsesojuzn [Increasing the efficiency of using broodstock of pigs. All-Union]. Akad. s.-h. nauk im. V. I. Lenina. M: Kolos, 179 p.

14. Lugovyj, S. I. and Lyhach, V. Ja., 2015. Vlyjanye vozrasta dvuhporodnыh svynomatok na yh vosproyzvodytel'nыe kachestva [Influence of age of two-breed sows on their reproductive qualities]. Tehnologija vyrobnyctva i pererobky produkcii' tvarynnyctva : zb. nauk. prac' Bilocerk. nacional'nyj agrar. un-t. Bila cerkva, vol. 1(116), pp. 45-49.

15. Moraru ,I., Fogl'majr, T., Grissler, A. et al. 2012. Jenciklopedija vosproizvodstva [Encyclopedia of reproduction]. K. : Rema-Print, $225 \mathrm{p}$.

16. Nemchenko, V. V., 2012. Prodovol'cha bezpeka Ukrai'ny [Food security of Ukraine]. Zbirnyk naukovyh prac' VNAU. vol. 2. issue. $4,70 \mathrm{p}$.

17. Perevojko, Zh, A. and Kosilov, V. I., 2014. Vosproizvoditel'naja sposobnost' svinomatok krupnoj beloj porody i ejo dvuh-trjohporodnyh pomesej [Reproductive ability of sows of large white breed and its two-three-breed crosses]. Izvestija Orenburgskogo gosudarstvennogo agrarnogo universiteta, vol. 6, pp. 161 - 163.

18. Piotrovych, N. A., 2017. Formuvannia vidtvoriuvalnykh yakostei svynomatok ta otsinka yikh kombinatsiinoi zdatnosti [Formation of reproductive qualities of sows and evaluation of their combination abilityi]. Dissertation abstract. Mykolaiv

19. Plohinskij, N. A., 1970. Biometrija [Biometrics]. M. : Mosk. un-t.

20. Plokhinskiy N. A., 1969. Rukovodstvo po biometrii dlya zootekhnikov. [A guide to biometrics for zootechnicians]. M. Kolos. 259 p. 
21. Povod, M. G., Korzh, O. V. and Nesterov, A. M. 2017. Vplyv pory roku na vidtvorni jakosti svynomatok dans'koi' selekcii' [Influence of the season on the reproductive qualities of sows of Danish selection]. Visnyk Sums'kogo nacional'nogo agrarnogo universytetu. Serija: Tvarynnyctvo, issue 5(2), pp. $111-113$.

22. Povod, M. G. 2015. Povedinka ta produktyvnist' pidsysnyh svynomatok vprodovzh roku za riznyh umov utrymannja [Behavior and productivity of suckling sows during the year under different housing conditions]. Tehnologija vyrobnyctva i pererobky produkcii' tvarynnyctva, issue 2, pp. $35-41$.

23. Pol'ovyj, L. V. and Kul'chyc'ka, A. P., 2017. Formuvannja m'jasnoi' produktyvnosti ta ekonomichna efektyvnist' vyrobnyctva svynyny zalezhno vid tryvalosti pidsysnogo periodu [Formation of meat productivity and economic efficiency of pork production depending on the duration of the suckling period]. Visnyk agrarna nauka ta harchovi tehnologii', vol. 4 (98), pp. 190-191.

24. Pohodnja, G. S., Kornienko, P. P., Malahova, T. A. Kreneva, T. V. and Mamenko, A. M. 2017. Jeffektivnost' vyrashhivanija porosjat pri razlichnyh srokah ih otjoma [Efficiency of cultivation of piglets at various terms of their weaning]. Problemi zooinzheneriï ta veterinarnoï medicini, vol. 33. issue 1. pp. 129-134.

25. Rukovycan, O. V., 2018. Vplyv porjadkovogo nomeru oporosu na produktyvnist' svynomatok velykoi' biloi' porody [Influence of farrowing serial number on productivity of sows of large white breed]. Students'kyj naukovyj visnyk MNAU, pp. 243-249.

26. Sedilo, G. M., Pundyk, V. P., Kaplins'kyj, V. V. and Tesak, G. V., 2013. Rannje vidluchennja porosjat: perevagy ta problemy [Early weaning of piglets: advantages and problems]. Zbirnyk naukovyh prac' Instytutu sil's'kogo gospodarstva Karpats'kogo regionu NAAN. Peredgirne ta girs'ke zemlerobstvo i tvarynnyctvo, vol. 55 (II), pp. 176-177.

27. Starodubec', O. O. and Starodubec', A. A., 2015. Vpliv sezonu roku na vidtvorjuval'ni jakosti svinomatok [Influence of the season of the year on the reproductive qualities of sows]. Visnik agrarnoï nauki Prichornomor'ja. issue 2 (84). pp. $100-104$.

28. Strel'cov, V. A. and Lavrov, V. V., 2016. Estestvennaja rezistentnost' u porosjat pri razlichnyh srokah otema [Natural resistance in piglets at different weaning times]. Materialy Mezhdunarodnoj nauchno-prakticheskoj konferencii, posvjashhennoj 75letiju so dnja rozhdenija i 50-letiju trudovoj dejatel'nosti Zasluzhennogo dejatelja nauki RF, Zasluzhennogo uchenogo Brjanskoj oblasti, Pochetnogo professora Brjanskogo GAU, doktora sel'skohozjajstvennyh nauk, professora Gamko Leonida Nikiforovicha. pp. 280-283.

29. Tvorogova, E. V., 2013. Jekonomicheskie predposylki vnedrenija tehnologii sverhrannego ot\#ema porosjat [Economic prerequisites for the introduction of technology for superearly weaning of piglets]. Vestnik Chuvashskogo gosudarstvennogo pedagogicheskogo universiteta im. I. Ja Jakovleva, no. 2 (78), pp. 159-162.

30. Hristofor, L. H., 2006. Vlijanie sroka otema porosjat na produktivnost' i vosproizvoditel'nye kachestva svinomatok v uslovijah Jakutii [Influence of the weaning period of piglets on the productivity and reproductive qualities of sows in the conditions of Yakutia: author] avtoref. dis. na zdobuttja nauk. stupenja kand. s.-g. nauk: spec. 06.02.04 "Veterinarnaja hirurgija. Jakut. gos. s.-h. akad., $19 \mathrm{p}$.

31. Chernenko, A. V., 2008. Vplyv sposobu utrymannja svynomatok na produktyvni jakosti svynej riznyh genotypiv [Influence of a way of the maintenance of sows on productive qualities of pigs of various genotypes]. dys. kandydata s. -g. nauk : 06.02.04. Herson, $166 \mathrm{p}$.

32. Campbell, J. M., Crenshaw, J. D. and Polo, J., 2013. The biological stress of early weaned piglets. Journal of animal science and biotechnology. issue $1,19 \mathrm{p}$.

33. Jarvis, S., et al., 2008. Effects of weaning age on the behavioural and neuroendocrine development of piglets. Applied Animal Behaviour Science. issue 1, pp. 166-181.

34. Knecht, D., Srodon, S. and Duzinski K., 2015. The impact of season, parity and breed on selected reproductive performance parameters of sows. Arch. Anim. Breed, issue 58, pp. 49-56.

35. Lazarevich, A. N., Efimova, L.V. and Ivanova, O.V., 2017. Effectiveness analysis of crossbreding the hybrid sows with thoroughbred and terminal sires. In the World of Scientific Discoveries, Series B, issue 2, pp. 16-32.

36. Leibbrandt, V. D., Ewan, J. R. C. and Zimmerman D. R., 1975. Effect of weaning and age at weaning on baby pig performance. Anim. Sci, issue 40, pp. 1077-1080.

37. Marin, D., 2012. Nursing management and its impact on weaned piglet weight. Porcine Research, vol. 2, issue 1, pp. $23-26$.

38. Peet, B., 2003. Is it time to re-assess your weaning age? [electronic resource] Western Hog Journal.-Sheffield: Benchmark House, February. Access mode: www.thepigsite.com/articles/807/is-it-timeto-reassess-your-weaning-age

39. Turpin, D. L, Langendijk, P, Chen, T. Y. and Pluske, J. R., 2016. Intermittent Suckling in Combination with an Older Weaning Age Improves Growth, Feed Intake and Aspects of Gastrointestinal Tract Carbohydrate Absorption in Pigs after Weaning. Animals (Basel). 2016;6(11):66. Published 2016 Oct 25. doi:10.3390/ani6110066.

40. Ushakova, S., 2016. Influence of boars of different breeds on reproductive qualities of sows in multipedigree crossbreeding. Visnyk Agrarnoi Nauky, issue. 94 (2), pp. 68-69.

41. Whiting, T. and Pasma, T., 2008. Isolated weaning technology: humane benefits and concerns in the production of pork. The Canadian veterinary journal, issue 49, pp. 293-301.

Shvachka Ruslan Petrovich, Postgraduate student, Sumy National Agrarian University (Sumy, Ukraine)

Influence of lactation duration, season, age, breed combinations of sows on reproductive indicators of their produc-

tivity

In the article, by conducting a four-factor analysis of variance, the strength of the influence of lactation duration, age of sows, their breed combinations at different times of the year, and the interaction of these factors on the change of individual indicators of Вісник Сумського національного аграрного університету 
reproductive productivity of sows. It was found that the duration of the suckling period most significantly affects the nest weight of piglets at weaning - 73,0\%, - the average weight of one piglet at weaning - $64,4 \%$, - the absolute growth of piglets in the weaning period $-63,0 \%$, the average daily gain in this period $-8,4 \%$, relative gains in the suckling period $-1,2 \%$, the safety of piglets before weaning $-0,7 \%$ and the weight of the nest at birth $-1,9 \%$ and the number of piglets at weaning - $0,4 \%$ and not had an effect on the total number of piglets at birth and the fertility of sows. The season had an impact on the safety of piglets before weaning - 2,1\%, their number at weaning and the average daily gain in the suckling period of $1,6 \%$, relative gains in this period - 1,2\%, the absolute growth of piglets in the suckling period - $0,6 \%$, the weight of one piglet and the weight of the nest at weaning - respectively $0,5 \%$ and $0,4 \%$ and did not affect the total number of piglets at birth, fertility and nest weight of piglets at birth. The age of the sow had a probable effect on all studied indicators. He had the greatest impact on the number of weaned piglets $-8,3 \%$, their safety before weaning $-6,7 \%$, the average daily gain in the suckling period $-4,5 \%$, the weight of the nest of piglets at birth $-2,3 \%$ and the fertility of sows $-2,2 \%$, the absolute growth of piglets in the suckling period 2,0\%, the weight of one piglet and the weight of the nest at weaning $1.9 \%$, the total number of piglets at birth $-1,7 \%$, the relative growth of piglets in the suckling period $-1,2 \%$, the weight of the nest of

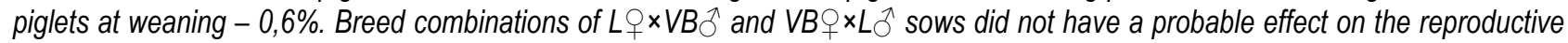
performance indicators studied.

Key words: sow, piglets, suckling period, weaning period of piglets, fertility, safety, breed combination.

Дата надходження до редакції: 09.08.2021 р. 